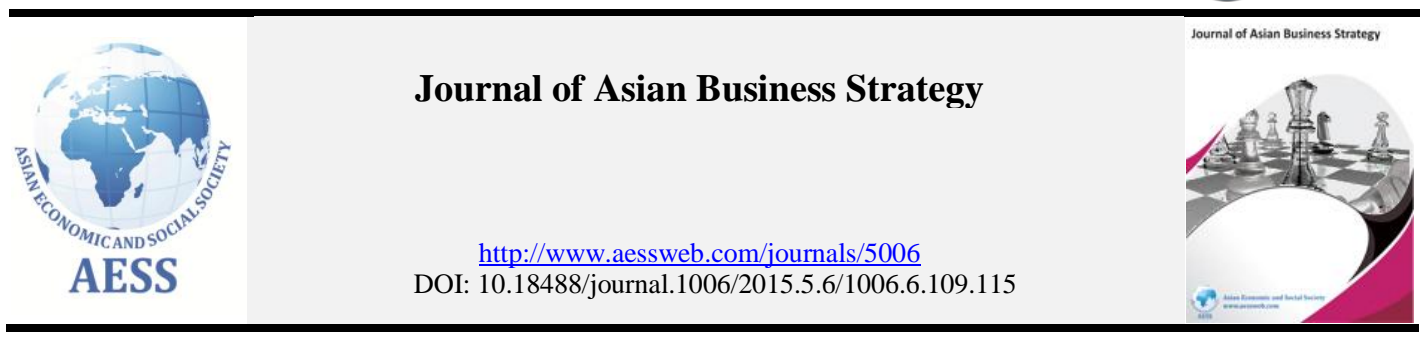

\title{
THE ROLE OF CORPORATE GOVERNANCE MECHANISM IN OPTIMIZING FIRM PERFORMANCE: A CONCEPTUAL MODEL FOR CORPORATE SECTOR OF PAKISTAN
}

\author{
Ahsan Akbar \\ Lecturer in Finance; University of Education, Lahore, Pakistan and PhD Scholar; School of \\ Accounting and Finance, Zhongnan University of Economics and Law, Wuhan, P.R. China
}

\section{Article History: \\ Received: 22 April 2015 \\ Revised received: 15 May \\ 2015 \\ Accepted: 18 June 2015 \\ Online available: 20 July \\ 2015}

\section{Keywords:}

Corporate governance, firm performance, conceptual framework

\begin{abstract}
Corporate governance refers to the processes that govern and direct firm managers to take decisions that are in line with the shareholders goal of wealth maximization. Various studies have been conducted in developing countries including Pakistan to investigate the relationship between corporate governance and firm performance mostly by using the conventional measures of corporate governance. The result of these studies suggests that corporate governance positively and significantly contributes towards firm performance. The aim of this study is to incorporate some important policy measures related to major players of corporate governance that are of significant importance in establishing an effective corporate governance structure in addition to the conventional measures of corporate governance. Inclusion of these variables will help the firms to create an effective corporate governance system that will lead to an increased firm performance.
\end{abstract}

\section{INTRODUCTION}

Corporate governance is concerned with the mechanism or organization employed to safeguard the rights of shareholders. The need for corporate governance stems from the problem of agency issue. In a corporate system managers have more power and information than isolated shareholders. As a shareholder is interested to get a return on his investment in the form of dividend or capital gain but the aim of the managers may be somewhat different like securing his job, get a promotion and the like.

Corporate governance is a topic which is now of global importance for the researchers, practitioners, and corporate governing bodies. The cases of Enron and World com led the interest of the world towards the need to introduce a governance mechanism. Sarbanes-Oxley act was also a step in this regard to ensure transparency and suitable disclosure of financial matters of the firm. Codes of corporate governance were first introduced by the Organization for Economic Cooperation \&

Corresponding author's

Email address: $\underline{\text { ahsan_finance@ @otmail.com }}$ 
Developments (OECD) in the year 1999. Till then they captured the attention of a vast variety of stakeholders like policy makers, shareholders and companies. These codes or doctrine provide common standards of corporate governance and good practices those are applicable in diverse corporate setups. Majority of European countries have in work the corporate governance structure from its beginning and now they are well ahead in realization of corporate governance than developing countries and emerging economies.

Pakistan was relatively late in the introduction of corporate governance strategy and principles. Securities and Exchange Commission of Pakistan is the body that finalized the codes of corporate governance in the year 2002. However to further advance the corporate governance practices in Pakistan SECP introduced the institute of corporate governance in the year 2004. Yet corporate governance is still at an initial stage and lacks in proper implementation because of various hazards. A variety of empirical literature is available on how corporate governance can impact the firm operating and financial performance both in the context of developing and developed economies. The results of the studies robustly suggested that an effective corporate governance structure can direct the management to work in a way that leads enhanced performance of the firm by preserving the rights of shareholders.

A variety of emperical work is done in developing countries including pakistan to observe the relationship between corprate governance and its impact on the firm performance. The majority of researchers of developing countries as wells as in Pakistan have measured the effectiveness of the corporate governance system by using the conventional measures of corporate governance like ownership concentration, board size, board composition, CEO/Chair duality, role of audit and other committees because this information can be easily extracted from the firm's annual reports. However the aim of this paper is to develop a conceptual model by incorporating some other determinants of corporate governance like the regulations employed by the corporate governing body as well as board of directors to ensure an effective corporate governance system in addition to the conventional determinants. The application of this model will increase the corporate governance effectiveness that will subsequently increase the firm performance.

\subsection{Objective of the study}

Pakistan is a country where the field of corporate governance is yet at infancy stage and a lot of work is still needed to be done for the effective corporate governance and control. Securities and exchange comission of Pakistan is the regulatory authority that oversees the performance of corporate sector.focus of the past researches in this field especially in Pakistan has been mainly upon the quantitative and conventional measures like Ownership concentration, board size, board composition, CEO/Chair duality, role of audit and other committees. However The objective of this study is to develop a conceptual model by including the factors of corporate governance which are related to rules that govern the board of director, executives of the firms and other stakeholders. The implementation of these regulatory measures alongwith the conventional tools will strenghten the corporate governance system which in turn will increase the firm performance.

\section{MEASURES OF CORPORATE GOVERNANCE AND FIRM PERFORMANCE}

\subsection{Conventional measures}

The key conventional quantitative measures used to guage the effectiveness of corporate governance structure in a corporate setting mainly includes ownership concentration, board size, board composition, and dual role of CEO and Chairperson of board of directors. The emperical findings regarding the impact of these variables on firm performance is detailed below.

\subsubsection{Ownership concentration}

To understand the impact of ownership concentration on firm performance a study was conducted by Grosfeld (2006) the data includes all the non financial firms listed on the Warsaw stock exchange 
from the year 1991 upto 2003. The findings of the study indicated that firms that belongs to the sector where high technology is used have dispersed ownership while the firm belonging to more mature sctors have higher ownership concentration. Moreover the results also suggests that firms with concentrated ownership pattern performs better than firms with dispersed ownership pattern. The value found by ordinary least square regressions becomes even more strong when the endogeneity of ownership is controlled.

From the context of Pakistan Ahmed et al. (2012) explored the impact of concentrated ownership on firm performance. Panel data of 100 non financial firms that are listed on the Karachi stock exchange was used. From the year 2005 upto 2010. Firm performance was measured by growth in sales return on assets and share price growth. The results of the study demonstrated that ownersip concentration is negatively correlated with share price growth that represents market performance while ownership concentration was positively correlated with return on assets and sale growth that are the indicators of financial perofromance of firm.

From the developed countries perspective Balsmeier and Czarnitzki (2010) investigated the relationship of ownership concentration with firm performance in 28 Central and Eastern Europeantransition economies. The data was taken over a period ranging from 2002 to 2009. Finding revealed a u-shaped relationship between ownership concentration and firm performance. The firm performance increases up to $50 \%$ ownership concentration but after passing a peak value of $55 \%$ increased ownership concentration negatively impact the firm performance. This is because of the fact that the block holders tend to enjoy these benefits rather than sharing them with the minority shareholders.

\subsubsection{Board size}

The literature about the impact of board size on firm performance however provides mix findings. A too small or too large board size have negative impact on firm performance. Guest (2009) investigated the impact of board size on the performance of firms using a large sample of 2746 listed companies from the year 1981 to 2002.Board size was measured by the number of directors on the board and firm performance was measured by profitability, return on equity and Tobin's Q. the analysis of the data revealed that board size has a strong negative impact on these firm performance variables.these evidence support the argument that communication and decision making problem weaken the effectiveness of larger board size. Furthermore findings suggest that negative relation in board size and firm performance is strongests in large firms.

However from the Asian countries perspectrive Weterings and Swagerman ( 2011) conducted a study to trace out the impact of board size on firm value using a sample of 155 property firms and real estate investment trust listed in the exchanges of Singapur, Hong Kong and Malaysia. A positive relationship was observed between board size and firm value form the property firms. However the results forreal estate investment trust was insignificant. Garg (2007) investigated the influence of board size and board on firm performance on a sample of indian firms. Firm performance was measured by Tobin's Q, return on assets and total assets turnover thwe research results recommend that there is an inverse relationship between board siz and firm performance.

To find the similar relationship Topak (2011) used panel data technique on a sample of Turkish firms from 2004 to 2009. Being an emerging market Turkey has unique ownership structure and legal system. Unlike the previous researches this study demonstrate that there is no relationship between the board size and Turkish firm performance.

\subsubsection{Board composition}

Board composition is a term used to elaborate the proportion of executive or inside and non executive or outside directors on the board. The past studies on the impact of board compositin on firm performance suggest that presence of non executive directors on the board ensures an effective 
oversight over the activities of the firm management which in turn leads to superior firm performance. Heenetigala \& Armstrong (2007); Choi et al. (2007); Yasser et al. (2011) found that presence of outside board member have a positive relationship with firm performance.

\subsubsection{CEO/ Chair duality}

If the firm CEO is also the chairman of the board this represents the CEO chair duality. The proponents of the agency theory says that CEO Chair duality will weaken the control mechanisim and negatively influence the role of board members evaluating the activities of firm managers. The studies of Ujunwa (2012), Heenetigala \& Armstrong (2007), Yasser et al. (2011) found that CEO chair duality have a negative impact upon the firm performance.

\subsection{Regulatory measures}

Majority of the studies conducted in the developing countries especially in the case of Pakistan attempted to quantify these measures of corporate governance as ownership concentration, board size, CEO chair duality, board composition etc to analyse their relationship on different performance measures of the firm. But there exsit a variety of unique and qualitative indicators that are of considerable importance to for effective corporate governance.

A detailed insight into the work of Brown and Caylor (2006) and some renowned corporate governance sytems like ISS CGQ, the Corporate Library (TCL) and GMI suggests that effective ness of corporate governance structure can not be judged solely on the basis of the conventional measures of corporate governance like ownership concentration, board size, board composition, CEO/Chair duality etc but the firms policies and regulation regarding some key players like board of directors, CEO and other senior level management as well as its responsiveness towards some major stakeholders like shareholders, customers and society, rules pertaining to survelance and disclosure are also of significant importance for the development of an efficient corporate governance culture that leads towards an enhanced firm perfrmance.

Corporate rating agencies of the developed countries have taken considerable steps to incorporate these important governance factors into their rating systems. But most of the studies conduted in the developing countries perspective are merely considering the published data to measure the effectiveness of corporate governance that leads to increase in firm performance.in this an integrated approah is used by taking into consideration the conventional measures of corporate governance that are previously discussed much in the developing countries literature plus the policies and regulation pertaining to some important players of the corporate governance. a brief description of the important regulations regrading Directors, CEO and other stakeholder is as under.

Brown and Caylor (2006)_ conducted a comprehensive study on 1868 firms and developed a summary of corporate governance components that effects the firm performance and value by thoroughly examining various corporate governance indicies. The results hilighetd seven indicators named as (GV7) that establishes a strong corporate governance structure. The results revealed that board of directors having relevent and professional qulification will positivily impact the firm performance. Secondly firm must establish a policy regarding the retirement age of the directors. And election of the board members should occur after every year so that if the board members are not preserving the rights of shareholders they should be replaced by more effective candidates.and former CEO of the firm should not be the part of board because of the fact that the former CEO working on the board can dictate the terms and the performance of new CEO may suffer. Moreover board members must have attended $75 \%$ of the board meeting and must have a valid excuse of not attending any meeting.if the board members are frequently absent from the meetings then it can negatively impact firm strategic planning and policy decisions.another important qualitative governance variable explored in this study that firm must have a policy regarding the rotation of external auditor to ensure the true and fair view of financial matters to the stakeholders. 


\subsubsection{Director regulations}

Directors play an important role in deciding the strategic direction and overall policy making of the firm so the corporate regulatory authority must establish some important regulation in order to ensure the better functioning of the governance mechanism.so if the firm's directors have relevent education and have acquired professional training they can perform better as compared to those members who does not have the relevent education and skills.secondly firm must have a defined regulation regarding the retirement age of a board member so that older members could be replaced by more energetic directors that can contribute better than their elder counterparts.moreover it should be clearly mentioned in company regulation that no former CEO could be the part of the board as the evidence suggests that former CEO's tends to dictate the terms and due to which the performance and decision making ability of the upcoming CEO may suffer. Onother important regulation related to the board of Directors is that the company must have a policy to hold annual elections of board of directors so that shareholders can vote out those members that are not contributing well to increase the firm performance.regulations must also guide clearly the compensation that will be made to the board members. The compensation should be justifiable and should be inline with the qualification and experience of the board members. the performance of the board members should be reviewed by the shareholders and the regulations sholud made it compulsry for the board members to attend the board meetings. The regulatory authority must also oversight the related party transactions. Related party tranactions are those that occurs between board members CEO and other senior management personnels.

\subsubsection{Executive regulations}

The board of director must establish the regulations regarding executives of the firm especially about the Firm CEO to ensure that executives are pursuing the goal of shareholders. The CEO of the firm is usually a highly paid professional because of nature of the job and the role he/she plays in an organization. But the compensation made to the CEO should not be exceptionally high and should be justifiable on grounds of firm performance. Compensation includes salary and other perks and benefits to which the CEO is entitled to. Especially if the firm's financial performance is declining an increase in the compensation of CEO is questionable. Moreover the short term as well as long term performance should be evaluated by the board on periodic basis. In addition to this regulations must exist regarding the compensation criteria of senior level management like the heads of different functional areas of the firm. And the board should review that top officials of the management are responsive towards the interest of shareholders. So, if the firm has appropriate policies and regulations regarding the firm's executive and senior management and these policies are properly implemented it will leads towards the establishment an effective corporate governance structure that maximizes firm performance.

\subsubsection{Other regulations}

The purpose of an effective governance system is protecting the rights of the shareholders. So the shareholders must have right to call special meeting on the matters of considerable importance.Moreover the firm must respond properly towards the rights of the society and must fulfill its social responsibility. A socially responsive firm will be able to improve its image in stakeholders mind and will have a long term survival in the market. The code of ethics must be clearly defined that must outline the rights and responsibilities of various stakeholders of the firm. The firm must have a policy to rotate the external auditor to ensure the true and fair view of financial information. Importantly the firm must disclose the compensation paid to the directors and executives of the firm. 


\section{An integrated approach to corporate governance}

\section{Conventional measures}

- Concentrated Ownership

- Appropriate Board size and composition

- CEO/Chair Duality does not exist

- Audit and other committees functioning

\section{Director regulations}

- Education of Directors

- Mandatory Retirement age

- Former CEO cannot serve on the Board

- Board member elected annually

- Director Compensation

- Oversight of related party transaction

- Compulsory attendance of board

Other regulations

- Justifiable CEO Compensation

- Executive performance evaluation

- Compensation of Senior Management

- Responsiveness to shareholder interest

- Auditor rotation policy exist

- Shareholders can call special meetings

- Corporate social responsibility met

- Code of ethics are defined

- Fair disclosure of financial information

- Disclosure of Executive \& Directors compensation

\section{CONCLUSIONS}

Corporate governance has been a hot issue in financial literature since some major financial manipulation and corporate frauds were observed due to lack of disclosure and poor audit and governing structure in large firms like Enron and World Com. Till then corporate governing bodies and board comittees are putting more emphasis on designing and implementing a strong corporate governance mechanisim. Majority of the researchers are of the view that an effective governance and control structure will force the managers to work in the best interest of the firm owners by providing full and accurate information in time. Moreover a good corporate governance system will ensure that managers are accepting only those projects that maximize the wealth of the shareholders thus resolving the inherent agency issue to a greater extent.

Developed countries have taken the lead in designing and implemeting corporate governance than developing ones. If we look into the literature one can easily find that a lot of work is done on how to design and implement an effective governance structure in a corporate setting. From the developed countries perspective work is also done to establish a corprate governance rating system to evaluate 
that how well the firms are doing ensure good corporate governance.However from the past few years studies are also conduted in many developing countries on the implementation of corporate governance and how a good corporate governance mechanisim can lead towards greater firm performance.

By taking the most relevent factors form the renowned corporate rating agencies and from the work of Brown and Caylor (2006) a conceptual model has been developed. In addition to the conventional determinants of corporate governance this model incorporates some unique and important regulatory measures related to the key players of corporate governance systemlike board of directors, CEO and stakeholders. The application of this model will surely help the Pakistani firms in establishing effective corporate governance mechanisim that will have a positive impact on various firm level performance measures.

\begin{tabular}{|c|}
\hline This study received no speci \\
\hline Competing Interests: The authors declare that they have no conflict of interests. \\
\hline $\begin{array}{l}\text { Contributors/Acknowledgement: All authors participated equally in designing and estimation of current } \\
\text { research. }\end{array}$ \\
\hline $\begin{array}{l}\text { Views and opinions expressed in this study are the views and opinions of the authors, Journal of Asian } \\
\text { Business Strategy shall not be responsible or answerable for any loss, damage or liability etc. caused in } \\
\text { relation to/arising out of the use of the content. }\end{array}$ \\
\hline
\end{tabular}

\section{References}

Ahmed, K., Sehrish, S., Saleem, F., Yasir, M., \& Shehzad, F. (2012). Impact of concentrated ownership on firm performance (Evidence from Karachi stock exchange). Interdisciplinary Journal of Contemporary Research in Business, 13(2), 201-210.

Balsmeier, B., \& Czarnitzki, D. (2010). Ownership concentration, institutional development and firm performance in central and eastern Europe. Centre of Euorpean Economic Research Discussion Paper, 10(96), 1-33.

Brown, L. D., \& Caylor, M. L. (2006). Corporate governance and firm valuation. Journal of Accounting and Public Policy, 25(2), 409-434.

Choi, J. J., Park, S. W., \& Yoo, S. S. (2007). The value of outside directors: Evidence from corporate governance in korea. Journal of Finance and Quantitative Analysis, 6(1), 270-292.

Garg, A. K. (2007). Influence of Board Size and Independence on Firm Performance: A Study of Indian Companies. Research, 32(3), 39-60.

Grosfeld, I. (2006). Ownership concentration and firm performance: Evidence from an emerging market. William Davidson Institute Working Paper Number, 834, 1-27.

Guest, P. M. (2009). The impact of board size on firm performance: Evidence from the UK. The European Journal of Finance, 15(4), 385-404.

Heenetigala, K., \& Armstrong, A. (2007). The impact of corporate governance on firm performance in an unstable economic and political environment: Evidence from Sri Lanka. 2012 Financial Markets \& Corporate Governance Conference, (p. 17).

Topak, M. S. (2011). The effect of board size on firm performance: Evidence from Turkey. Middle Eastern Finance and Economics, 43(1), 120-127.

Ujunwa, A. (2012). Board characteristics and the financial performance of nigerian quoted firms. Emerald Publishing Limited, 12(5), 1-30.

Weterings, J. P., \& Swagerman, D. M. (2011). The impact of board size on firm value: Evidence from the asian real estate industry. Asian Journal of Business and Management Sciences, 9(6), 2243.

Yasser, Q. R., Entebang, H., \& Mansor, S. A. (2011). Corporate governance and firm performance in Pakistan: The case of Karachi Stock Exchange (KSE)-30. Journal of Economics and International Finance, 3(8), 482-491. 